\title{
ENERGY SAVINGS BY MEANS OF FUEL CELL ELECTRODES IN ELECTRO-CHEMICAL INDUSTRIES
}

\author{
PROGRESS REPORT \\ For the period November 1, 1979 to January 31, 1980
}

\begin{abstract}
Amiram Bar-Ilan, Walter Juda, and Robert J. Allen and
\end{abstract} Robert W. Lindstrom

\author{
Submitted by \\ Prototech Company \\ 70 Jaconnet street \\ Newton Highlands, Massachusetts 02161
}

April 18, 1980

Prepared for

The U. S. Department of Energy

Under Contract No. DE-AC02-78ET25309 


\section{DISCLAIMER}

This report was prepared as an account of work sponsored by an agency of the United States Government. Neither the United States Government nor any agency Thereof, nor any of their employees, makes any warranty, express or implied, or assumes any legal liability or responsibility for the accuracy, completeness, or usefulness of any information, apparatus, product, or process disclosed, or represents that its use would not infringe privately owned rights. Reference herein to any specific commercial product, process, or service by trade name, trademark, manufacturer, or otherwise does not necessarily constitute or imply its endorsement, recommendation, or favoring by the United States Government or any agency thereof. The views and opinions of authors expressed herein do not necessarily state or reflect those of the United States Government or any agency thereof. 


\section{DISCLAIMER}

Portions of this document may be illegible in electronic image products. Images are produced from the best available original document. 
CONTENTS

Section

Page

I ABSTRACT

2 INTRODUCTION

3 TECHNICAL DISCUSSION

Zinc Electrowinning: Pure Hydrogen Fuel

3.1 Performance of Low Loaded Platinum and Typically Loaded Palladium Anodes

3.1.1 Background and Experimental

3.1.2 Discussion

3.2 Feed and Bleed Experiments at 50 and $150 \mathrm{~g} / 1 \mathrm{Zinc}$ and $100 \mathrm{~g} / 1 . \mathrm{H}_{2} \mathrm{SO}_{4}$

3.2.1 Background and Experimental

3.3 The Effect of the Mode and Rate of Electrolyte Stirring on the Quality of Cathodic zinc Plate

TECHNICAL DISCUSSION

The Hydrogen Anode for Electrowinning of zinc

3.4 Comparison of Performance Using Filtered Plant Feed Solution and Unfiltered and Filtered Purified Zinc Sulfate ( $B \& W$ ) Solutions

3.4.1 Background and Experimental

3.4.2 Discussion

3.5 The Effect of Feed Gas Hydrogen Concentration upon the Cell Voltage at Constant Total Gas Feed Rate and Current Density

3.5.1 Experimental Design

3.5.2 Discussion

3.6 The Effect of Hydrogen Gas Back Pressure upon the Cell Voltage at Constant Current Density

3.6.1 Experimental Design

3.6.2 Discussion 


\section{CONTENTS}

Section

Page

3.7 The Effect of Current Density upon Energy Consumption and Current Efficiency at Various $\mathrm{zn}^{++}$ Concentrations

3.7 .1 Introduction 25

3.7.2 Discussion 25

3.8 Trace Analysis of a Commercial-Size Thickness

Cathodic Zinc Plate Produced Using the Catalytic

$\mathrm{H}_{2}$ Electrode $\quad 28$

3.8 .1 Introduction 28

3.8.2 Discussion 29

3.9 Further Comparison of the Effects of Feed Solution Purification. Procedures 31

3.9.1 Introduction 31

3.9.2 Discussion 31

3.10 Comparision of Performance of Four Different 6" x 6" Platinum Anodes Produced by the Prototech Company.

3.10 .1 Introduction

3.10 .2 Discussion 


\section{TABLES}

Number

Page

$1 \mathrm{Zn}^{++}$and $\mathrm{H}_{2} \mathrm{SO}_{4}$ concentrations during an electrowinning test under feed and bleed (steady state) conditions

2 Effect of current density on current efficiency and power consumption and $100 \mathrm{~g} / \mathrm{I} \mathrm{H}_{2} \mathrm{SO}_{4}$ (steady state concentrations) at $55^{\circ} \mathrm{C}$

3 Comparison of performance using filtered plant feed $\mathrm{Zn}$ solution, unfiltered purified $\mathrm{ZnSO}_{4}$ solution and pH-5 filtered $\mathrm{ZnSO}_{4}$ Solution

4 Comparison of performance using $50 \mathrm{~g} / 1 \mathrm{zn}^{++}$and $150 \mathrm{~g} / \mathrm{l}$ $\mathrm{Zn}^{++}$at fixed acid concentration

5 Effect of feed hydrogen gas concentration upon the catalytic Pt anode performance

6 Effect of hydrogen gas backpressure upon the catalytic Pt anode performance

7 The effect of current density upon energy consumption and current efficiency at various $\mathrm{Zn}^{++}$concentrations

8 Trace analysis of a cathodic $\mathrm{Zn}$ plate produced by the $\mathrm{H}_{2}$ catalytic $\mathrm{Pt}$ anode

9 The effect of various purification procedures and $z$ inc concentrations upon cell performance

10 Comparison of platinum loadings of four Prototech Company catalytic anodes

11 Comparison of performance of four Prototech Company catalytic Pt anodes 


\section{FIGURES}

Number

Page

1 Comparison of discharge curves taken at various catalyst combinations

2 The effect of $z$ inc concentration upon cell voltage and discharge curves

3 Effect of $\mathrm{H}_{2}$ feed rate on cell voltage

4 Effect of hydrogen gas backpressure on cell voltage

5 The effect of current density upon current efficiency at various $\mathrm{Zn}^{++}$concentrations

6 Discharge curve of Pt anode \#3 in the zinc electrowinning cell 


\section{SECTION 1}

\section{ABSTRACT}

Zinc electrowinning data, obtained with hydrogen depolarized anodes operating in a plant feed electrolyte at $55^{\circ} \mathrm{C}$, are presented in this quarterly report for investigations involving the following:

a) Performance of an anode containing a low platinum loading, i.e. $0.09 \mathrm{mg} / \mathrm{cm}^{2}$ instead of the typical $0.33 \mathrm{mg} / \mathrm{cm}^{2}$, and an anode catalyzed with palladium instead of platinum.

b) Establishment of a feed and bleed system to maintain.: a constant electrolyte composition.

c) Exploratory experiments on the effect of the rate and mode of electrolyte flow on the quality of the zinc plate at high current densities.

d) Performance of the anode with feeds of varying degrees of purification pre-treatment, and containing either 50 or $150 \mathrm{~g} / 1 \mathrm{zn}^{++}$.

e) The effect upon cell voltage of decreasing the hydrogen flowrate to the anode by dilution of the feed gas with nitrogen.

f) The effect upon cell voltage of increasing the back pressure of the hydrogen gas fed to the anode.

g) The effect upon energy consumption and current efficiency of varying the current density and the $\mathrm{Zn}^{++}$concentration. 
h) Trace elemental analysis of a cathodic zinc plate of commericial-size thickness, as produced using the catalytic $\mathrm{H}_{2}$ anode.

i) Further comparison of the effects of feed solution purification.

j) Performance of four different Prototech Pt anodes. 


\section{SECTION 2}

\section{INTRODUCTION}

Preliminary testing of a low loaded $\left(0.09 \mathrm{mg} / \mathrm{cm}^{2}\right)$ Pt hydrogen diffusion anode for the electrowinning of zinc has been extremely encouraging. Reduction of the platinum content by a factor of over three did not increase anode polarization (as compared to a $0.33 \mathrm{mg} / \mathrm{cm}^{2}$ electrode) over the current density range of 9 to $72 \mathrm{ASF}$. Indeed, performance of the $0.09 \mathrm{mg} / \mathrm{cm}^{2}$ anode was slightly better than the standard above 27 ASF.

In an exploratory experiment, substitution of palladium for platinum as the hydrogen catalyst in the anode resulted in a $50 \mathrm{mv}$ increase in cell voltage at all current densities. This increase is quite small in comparision to the large voltage savings demonstrated by replacing the industrial lead anode with a hydrogen depolarized electrode. Also, the possibility of replacing platinum with a cheaper catalyst is obviously of great interest.

In zinc electrowinning plants, the zinc and sulfuric acid concentrations are kept constant at steady state conditions. This is accomplished by employing a feed and bleed system. Such a system has been developed for experimental cells (2" $\times 2 "$ and 6" $\times$ " 6"). Analytical data for both $z$ inc and sulfuric acid concentrations confirm constant steady state levels. 
In order to maintain a smooth, dense cathodic zinc plate at high current densities ( $>36 \mathrm{ASF}$ ), it has been found necessary. to change the mode and rate of electrolyte stirring. Increasing the current density required a proportional increase in the rate of agitation.

Experiments were undertaken to re-establish the suitability of the hydrogen depolarized catalytic platinum anode for the handling of plant feed solutions, and to examine the dependence, if at all, of cell performance upon feed purification pre-treatment. Steady-state (i.e., continuous liquid electrolyte feed and bleed) operation of a $2 " \times 2 "$ cell has indeed confirmed the low cell voltage requirement for handing a typical Anaconda plant feed.

Furthermore, current efficiency and power consumption have been found to be insensitive to the degree of purification pre-treatment of the feed, at liquid electrolyte concentrations of $100 \mathrm{~g} / 1 \mathrm{H}_{2} \mathrm{SO}_{4}$ and both 50 and $150 \mathrm{~g} / 1 \mathrm{zn}{ }^{++}$. However, as noted previously, both current efficiency and power consumption depend on the ratio of the acid and $\mathrm{zn}^{++}$ concentrations.

Additional experiments have been performed to determine the effect upon cell voltage of decreasing the feed of hydrogen gas to the catalytic anode of a 6" $\times$ 6" cell, from values rather in excess of to values below the exact amount theoretically required to maintain the current. It was found that, when the current density was fixed, the cell voltage 
and consumption of hydrogen remained remarkably constant, the latter at the theoretical minimum, until the $\mathrm{H}_{2}$ feed rate was decreased below the theoretical minimum. At that point the cell voltage began to increase, indicating the production of molecular oxygen at the anode.

Another series of experiments was conducted with a 6" $\mathrm{x}$ 6" cell in which the pressure of pure hydrogen gas fed to the catalytic anode was increased stepwise to a value of $32 \mathrm{~cm} \mathrm{H} \mathrm{H}_{2} \mathrm{O}$ above atmospheric. This effected a decrease in cell voltage from $1.68 \mathrm{v}$ to $1.51 \mathrm{v}$.

In a 6" a.6" (active electrode area) cell, the current density was varied between 36 and $90 \mathrm{ASF}$, at $\mathrm{Zn}^{++}$concentrations of 50,80 and $90 \mathrm{~g} / \mathrm{l}$. The current efficiency was observed to increase modestly with current density, except at the lowest $\mathrm{Zn}^{++}$concentration, at which the current efficiency was insensitive to current density. Power consumption (in $\mathrm{KWH} / 1 \mathrm{~b} \mathrm{zinc}$ ) increased consistently with current density and $\mathrm{Zn}^{++}$concentration.

A trace element analysis of the zinc plate deposited at the cathode demonstrated high purity and, as reflected by a very low sulfur content, the solidity and non-porosity of its surface.

A comparison of the performance of the catalytic Pt anode using feed electrolyte solutions of four different methods of pre-treatment revealed a remarkable insensitivity to feed purification approach. 
Finally, discharge curves were obtained for four Prototech Pt anodes of widely varying times in service, but essentially equal Pt loading. The performances of the four anodes were nearly indistinguishable. 


\section{SECTION 3}

\section{TECHNICAL DISCUSSION}

\section{Zinc Electrowinning}

\section{Pure Hydrogen Fuel}

\subsection{Performance of Low Loaded Platinum and Typically Loaded Palladium Anodes}

\subsubsection{Background and Experimental}

During the previous contract period, zinc electrowinning experiments were conducted with hydrogen anodes having a Pt catalyst loading of about $0.3 \mathrm{mg} / \mathrm{cm}^{2}$. Preliminary experiments with electrodes containing approximately one third of the regular Pt loading, i.e. $0.090 \mathrm{mg} \mathrm{Pt} / \mathrm{cm}^{2}$, or $0.3 \mathrm{mg} / \mathrm{cm}^{2} \mathrm{Pd}$ instead of $\mathrm{Pt}$ have been carried out during this contract period with encouraging results.

A comparision of the discharge curves of the various types of anodes is shown in Figure 1. The data were obtained in a $2 " x 2 "$ cell. Studies with low loaded Pt anodes as well as Pd anodes will be continued, and studies of anodes with low loaded Pt-Pd mixtures will be initiated.

\subsubsection{Discussion}

The three discharge curves shown in Figure 1 are linear. The $0.3 \mathrm{mg} / \mathrm{cm}^{2}$ Pd curve is parallel to that of the $0.3 \mathrm{mg} / \mathrm{cm}^{2}$ standard Pt curve but is higher by about 0.05 volts. The low loaded Pt anode curve is also linear, and 
CELL VOLTAGE

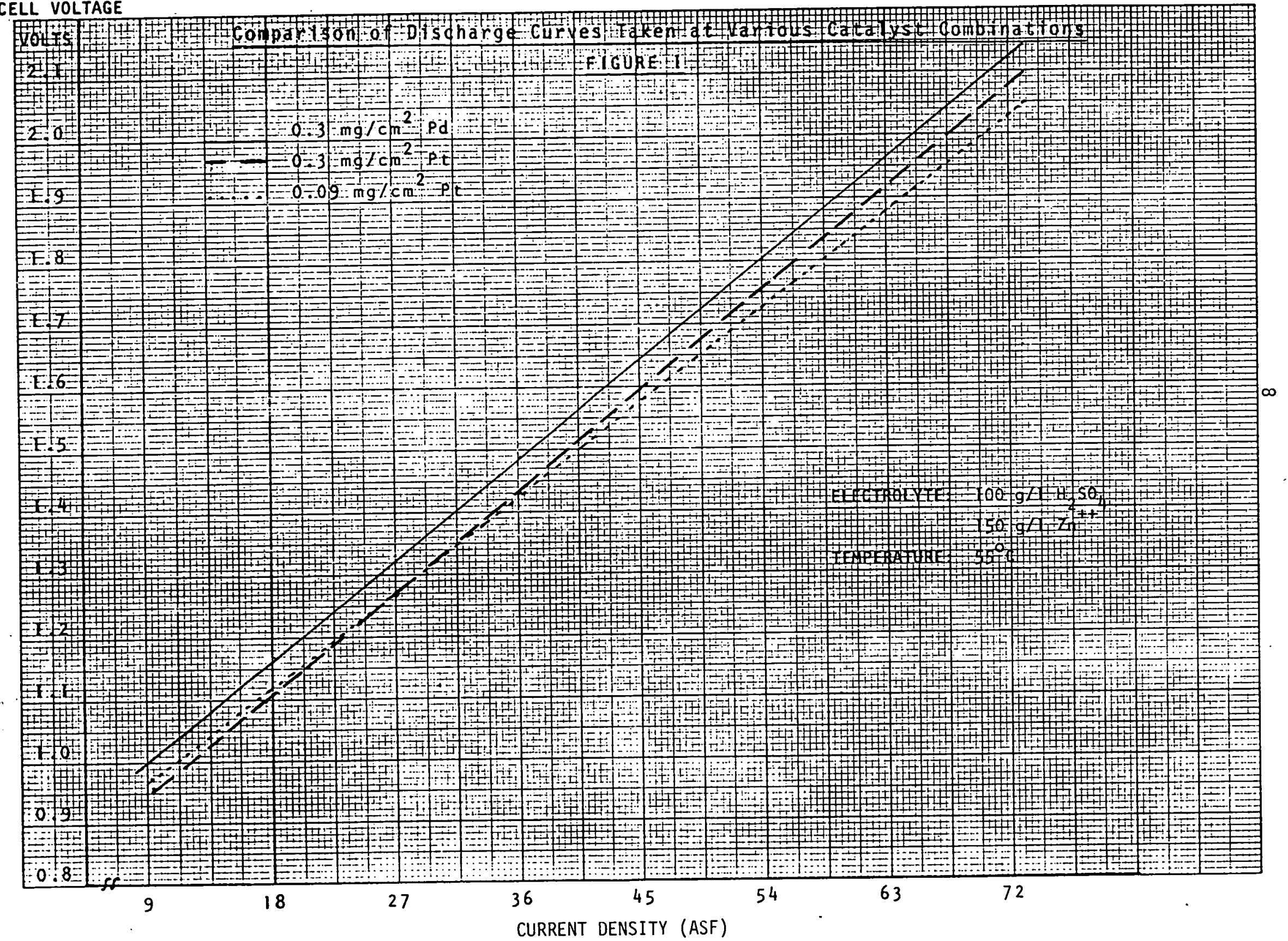


while not quite parallel to the above two curves it is very close to the standard $0.3 \mathrm{mg} / \mathrm{cm}^{2} \mathrm{Pt}$ data. It remains for life tests to show the stability of the performance of low loaded Pt and typicàlly loaded Pd electrodes. Until now, $0.3 \mathrm{mg} / \mathrm{cm}^{2} \mathrm{Pt}$ anodes have been tested for hundreds of hours in zinc electrowinning hardware without signs of performance deterioration, and they are considered to be the standard for comparison. In view of the known ability of palladium to act as a hydrogen "sponge" as well as a catalyst, low catalyst loadings consisting of Pd-Pt mixtures will be investigated.

3.2 Feed and Bleed Experiments at 50 and $150 \mathrm{~g} / 1 \mathrm{Zinc}$ and $100 \mathrm{~g} / 1 \mathrm{H}_{2} \mathrm{SO}_{4}$

\subsubsection{Background and Experimental}

Industrial $\mathrm{Zn}$ electrowinning is carried out under feed-and-bleed conditions in which constant, steady-state $\mathrm{Zn}^{++}$and free $\mathrm{H}_{2} \mathrm{SO}_{4}$ acid concentrations in the bulk electrolyte are maintained. Under these conditions a near neutral solution containing a high concentration of $\mathrm{Zn}^{++}$is fed into the cell and a low $\mathrm{Zn}^{++}$, but high acid, solution is bled from the cell with the bleed used as a leach of zinc concentrate to prepare a new near neutral feed.

These conditions were approximated in a series of experiments conducted in the $2 " x 2$ " cell, in which the steady state $\mathrm{Zn}^{++}$concentration was 50 or $150 \mathrm{~g} / 1$ while the acid was held constant at $100 \mathrm{~g} / 1$. A comparison of typical discharge curves at steady state concentrations is shown in Figure 2 . 
In another series of experiments utilizing an electrolyte of ca. $50 \mathrm{~g} / 1 \mathrm{Zn}^{++}$and $100 \mathrm{~g} / 1 \mathrm{H}_{2} \mathrm{SO}_{4}$, plating was carried out at current densities between $36 \mathrm{ASF}$ and $144 \mathrm{ASF}$, the duration of the runs chosen so as to produce comparable weights of $\mathrm{zn}$ deposit at each current density. Table 1 shows the steady state analytical data for both $\mathrm{Zn}^{++}$and $\mathrm{H}_{2} \mathrm{SO}_{4}$ concentrations of the bulk electrolyte, while Table 2 shows the results of the effect of increased current densities on current efficiency and power consumption at the above steady state concentrations.

Utilizing the steady state concentrations of zinc and acid during four of the electrowinning runs at $55^{\circ} \mathrm{C}$, listed. in Table 1, we found unexpectedly (see Table 2) a substantially constant current efficiency of $86 \%-878$, substantially independent of current density in the range of 36-144 ASF. When the cell was operated at $100 \mathrm{~g} / 1 \mathrm{zn}$ and above, with the same acidity", the current efficiency ranged from $90 \%$ to ca. $94 \%$ with increasing current density. The fact that the current efficiency is lower at the $50 \mathrm{~g} / 1 \mathrm{zn}^{++}$than at the $100 \mathrm{~g} / 1 \mathrm{Zn}^{++}$concentration (both electrolytes containing about $100 \mathrm{~g} / 1$ of free acid) is clearly attributable to the lower free acid-to-zinc ratio of the latter.

Figure 2 shows the comparison of discharge curves obtained at high and low $\mathrm{Zn}^{++}$concentrations. The two curves 
TABLE 1

$\mathrm{Zn}^{++}$and $\mathrm{H}_{2} \mathrm{SO}_{4}$ concentrations during an electrowinning test under feed and blec:d (steady state) conditions

\begin{tabular}{ccc}
$\begin{array}{c}\text { Elapsed Time } \\
\text { (Hours) }\end{array}$ & $\mathrm{zn}^{++} \mathrm{g} / 1$ & $\mathrm{H}_{2} \mathrm{Su}_{4} \mathrm{~g} / 1$ \\
\hline 0 & 49.72 & 100.54 \\
1 & 49.41 & 100.69 \\
2 & 49.34 & 100.25 \\
3 & 49.87 & 101.45 \\
4 & 49.65 & 100.59 \\
5 & 49.82 & 100.71 \\
\hline
\end{tabular}




\section{TABLE 2}

Effect of current density on current efficiency and power consumption and $100 \mathrm{~g} / 1$ $\mathrm{H}_{2} \mathrm{SO}_{4}$ (steady state concentrations) at $55^{\circ} \mathrm{C}$

\begin{tabular}{rccc}
$\begin{array}{c}\text { Current } \\
\text { Density } \\
(\text { ASF) }\end{array}$ & $\begin{array}{c}\text { Duration } \\
\text { of run } \\
\text { (Hours) }\end{array}$ & $\begin{array}{c}\text { Current } \\
\text { Efficiency } \\
(8)\end{array}$ & $\begin{array}{c}\text { Power Consumption } \\
\text { KWH/1bs Zn }\end{array}$ \\
\hline 36 & 8 & 37.1 & 0.59 \\
45 & 7 & 89.4 & 0.64 \\
72 & 4 & 87.4 & 0.70 \\
90 & 3 & 86.6 & 0.80 \\
120 & 3 & 86.1 & 0.97 \\
144 & 3 & 86.1 & 1.09
\end{tabular}




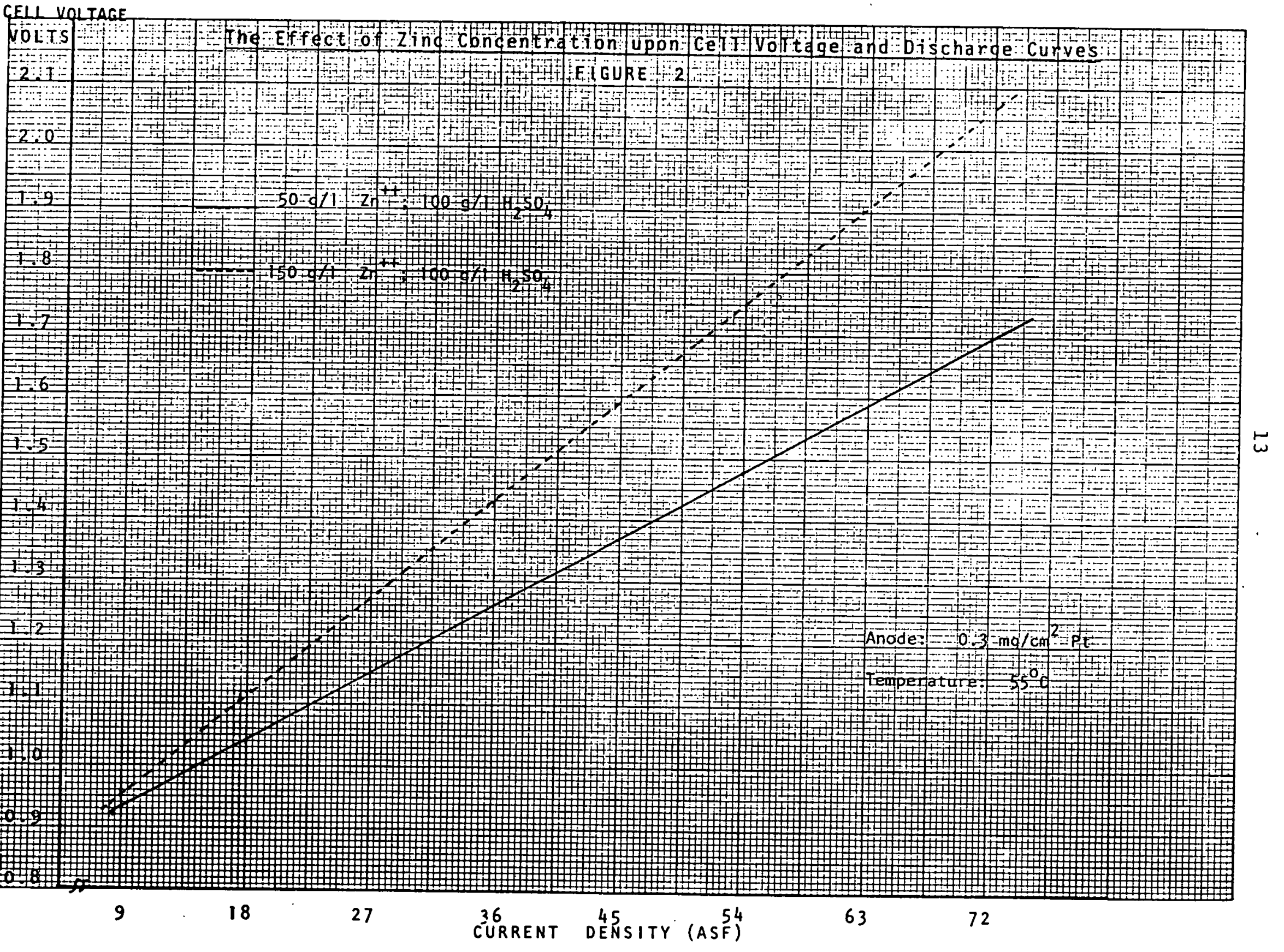


are linear but not parallel. Here, the $50 \mathrm{~g} / 1 \mathrm{Zn}^{++}$electroIyte has a higher conductivity than that of $150 \mathrm{~g} / 1 \mathrm{zn}^{++}$, at a fixed acid level $(100 \mathrm{~g} / \mathrm{l})$. The difference is about $4.6 \times 10^{-3}$ ת-sq ft. Thus, a concentration will be determined experimentally that balances the benefit of higher conductivity at lower concentration with that of higher current efficiency at higher concentration.

3.3 The Effect of the Mode and Rate of Electrolyte Stirring on the Quality of Cathodic Zinc Plate

In a series of experiments conducted at fixed $\mathrm{Zn}^{++}$and $\mathrm{H}_{2} \mathrm{SO}_{4}$ concentrations and at various current densities, it has been found that both the mode and rate of mixing of the electrolyte affect the quality of cathodic zinc deposited. As the current density is varied, the rate of electrolyte agitation must be changed in order to maintain a smooth and dense zinc cathodic plate. It has been found that at any current density the absence of agitation caused $\mathrm{H}_{2}$ bubbles to adhere to the zinc cathode, which resulted in the development of irregular depressions from the bottom to the top of the plate. On the other hand, if agitation was too fast, vertical stripes appeared in the deposited $z$ inc. In most cases, when a slow flow of electrolyte between the electrodes was maintained, $1 . e$. when turbulence was avoided, the physical quality of the zinc plate was superior. 
SECTION 3 CONTINUED

TECHNICAL DISCUSSION

The Hydrogen Anode for Electrowinning of Zinc

3.4 Comparison of Performance Using Filtered Plant Feed Solution and Unfiltered and Filtered Purified Zinc Sulfate $(B \& W)$ Solutions

3.4.1 Background and Experimental

During the previous contract period, it was. demonstrated that the Prototech hydrogen depolarized anode may be successfully used in the electrowinning of zinc from Anaconda plant feed solution at $55^{\circ} \mathrm{C}$, and that the required power consumption in $\mathrm{KWH} / \mathrm{lb}$ zinc was less than half that of a conventional lead anode based cell. The results were obtained in a batch operation, during which the $\mathrm{zn}^{++}$concentration decreased continuously while the acid concentration increased. The performance of a 2" $x 2$ " (active electrode area) Prototech anode based cell, using solutions of identical $100 \mathrm{~g} / 1$ sulfuric acid concentrations, either 50 or $150 \mathrm{~g} / \mathrm{l}$ $\mathrm{Zn}^{++}$, and with 3 varieties of purification pre-treatment, has now been examined under steady-state (feed and bleed) conditions, and is reported in Tables 3 and 4.

\subsubsection{Discussion}

For a filtered plant feed and both unfiltered and pH 5 filtered, purified $\mathrm{ZnSO}_{4}(\mathrm{~B} \& \mathrm{~W})$ solutions, all of which were maintained at a constant $\mathrm{Zn}^{++}$concentration of $50 \mathrm{~g} / 1$ (Table 3 ), 
TABLE 3

Comparison of Performance using Filtered Plant Feed Zn Solution, Unfiltered Purified $\mathrm{ZnSO}_{4}$ Solution and pH-5 Filtered $\mathrm{ZnSO}_{4}$ Solution

Experimental Conditions:

Current Density: $90 \mathrm{ASF}$

Cell Size: $2 " \times 2 "$

Pt Anode Loading: $0.33 \mathrm{mg} \mathrm{Pt} / \mathrm{cm}^{2}$

Temperature: $\quad 55^{\circ} \mathrm{C}$

Electrolyte: $50 \mathrm{~g} / 1 \mathrm{Zn}^{++}$

$100 \mathrm{~g} / 1 \mathrm{H}_{2} \mathrm{SO}_{4}$

$0.1 \mathrm{~g} / \mathrm{l}$ animal glue

steady state feed and bleed.

Source of Zinc

Plant feed filtered Solution

Unfiltered purified $\mathrm{ZnSO}_{4}$ (B \& W) Solution

pH-5 filtered purified $\mathrm{ZnSO}_{4}(\mathrm{~B} \& \mathrm{~W})$ Solution
Current Efficiency

87.18

0.81

$86.6 \%$

0.80

85.08

0.82
Energy Consumption ( $\mathrm{KWH} / \mathrm{lbs} \mathrm{Zinc}$ ) 
TABLE 4

Comparison of Performance using $50 \mathrm{~g} / 1 \mathrm{Zn}^{++}$ and $150 \mathrm{~g} / 1 \mathrm{zn}^{++}$at fixed acid Concentration

Experimental Conditions:

Current Density: $90 \mathrm{ASF}$

Cell Size: $2 " \times 2 "$

Pt Anode Loading: $0.33 \mathrm{mg} \mathrm{Pt} / \mathrm{cm}^{2}$

Temperature: $\quad 55^{\circ} \mathrm{C}$

Electrolyte: $100 \mathrm{~g} / 1 \cdot \mathrm{H}_{2} \mathrm{SO}_{4}$

$0.1 \mathrm{~g} / \mathrm{l}$ Animal glue

Steady state feed and bleed.

\begin{tabular}{ccc}
$\mathrm{Zn}^{++}$Concentration & $\begin{array}{c}\text { Current } \\
\text { and Source }\end{array}$ & $\begin{array}{c}\text { Energy Consumption } \\
(\mathrm{KWH} / \mathrm{Ibs} \mathrm{Zinc})\end{array}$ \\
\hline
\end{tabular}

Plant feed filtered

Solution

$\begin{array}{rrr}50 \mathrm{~g} / 1 & 87.1 \% & 0.81 \\ 150 \mathrm{~g} / 1 & 94.2 \% & 0.94\end{array}$

Unfiltered, purified

$\mathrm{ZnSO}_{4}$ (B\&W) Solution
$50 \mathrm{~g} / 1$
$86.6 \%$
0.30
$.150 \mathrm{~g} / 1$
$95.3 \%$
0.93

pH 5 filtered, purified

$\begin{array}{rll}50 \mathrm{~g} / 1 & 87.38 & 0.80 \\ 150 \mathrm{~g} / 1 & 94.88 & 0.93\end{array}$


there are negligible differences in current efficiency (range $85-87 \%$ ) and power consumption (range $0.80-0.83 \mathrm{KWH} / 1 \mathrm{~b}$ zinc).

Additional runs (Table 4) in which the steady-state $\mathrm{zn}^{++}$concentration was raised to $150 \mathrm{~g} / 1$ confirm the observation made in section 3.2 of this report, that both the current efficiency and power consumption increase as the ratio of acid to $\mathrm{Zn}^{++}$concentrations decreases. These results further confirm that performance--in terms of both current efficiency and power consumption--is independent of further purification pre-treatment of either the Anaconda plant or $B \& W$ feed solutions.

3.5 The Effect of Feed Gas Hydrogen Concentration upon The Cell Voltage at Constant Total Gas Feed Rate and Current Density

\subsubsection{Experimental Design}

In the scaled-up 6" $\times 6 "$ (active electrode area) cell, the hydrogen flowrate through to the catalytic platinum anode was reduced, at a constant total gas flow of $193 \mathrm{~cm} /$ minute, by mixing the hydrogen with varying proportions of nitrogen. The electrical current was maintained at 9 amps ( 36 ASF), and the consumption of hydrogen was monitored.

For a theoretical consumption of 1 mole of hydrogen for every 2 equivalents of electricity passed through the cell, the $\mathrm{H}_{2}$ requirement is $7.5 \mathrm{~cm}^{3}$ (STP)/minute per amp, or $67.5 \mathrm{~cm}^{3}$ (STP)/minute at 9 amps. Thus, when the $\mathrm{H}_{2}$ feed rate is lowered 
to the range of $67.5 \mathrm{~cm}^{3}$ (STP)/minute or below, alternative. electrode reactions are necessary to sustain a 9 amp current. The prevalence of such reactions will engender a change in overall cell voltage.

The results obtained at $55^{\circ} \mathrm{C}$ with $130 \mathrm{~g} / 1 \mathrm{zn}^{++}$and $100 \mathrm{~g} / 1 \mathrm{H}_{2} \mathrm{SO}_{4}$ are reported in Table 5 and Figure 3.

\subsubsection{Discussion}

The anode functions remarkably efficiently up to the point of $100 \% \mathrm{H}_{2}$ utilization. At $\mathrm{H}_{2}$ feed rates above that required by stoichiometry there is residual, unconsumed hydrogen which can be recirculated to the anode.

In the absence of sufficient hydrogen to sustain the reaction, $\mathrm{H}_{2}+2 \mathrm{H}^{+}+2 \mathrm{e}^{-}$, molecular oxygen is apparently produced as well at the catalytic anode, as in conventional zinc electrowinning cells, and the cell voltage increases correspondingly, since then a mixture of two electrowinning reactions takes place:

$$
\begin{aligned}
& \mathrm{H}_{2}+\mathrm{ZnSO}_{4} \rightarrow 2 \mathrm{H}^{+}+\mathrm{Zn}^{\circ}+\mathrm{SO}_{4}^{--} \\
& \mathrm{H}_{2} \mathrm{O}+\mathrm{ZnSO}_{4} \rightarrow{ }_{\frac{1}{2} \mathrm{O}_{2}}+\mathrm{Zn}^{\circ}+\mathrm{H}_{2} \mathrm{SO}_{4}
\end{aligned}
$$

3.6 The Effect of Hydrogen Gas Back Pressure upon the Cell voltage at Constant Current Density

3.6.1 Experimental Design

Experiments were conducted to examine the effect of changing the pressure of a pure hydrogen feed upon catalytic 
TABLE 5

Effect of Feed Hydrogen Gas Concentration upon the Catalytic Pt Anode Performance

Experimental Conditions:

Current Density: 36 ASF

Cell Size: 6" $\times 6 "$

Temperature: $55^{\circ} \mathrm{C}$

Electrolyte: $100 \mathrm{~g} / 1 \mathrm{H}_{2} \mathrm{SO}_{4}$

$0.1 \mathrm{~g} / 1$ Animal glue

$\mathrm{H}_{2}$ Gas Flow Rate ${ }^{*}\left(\mathrm{~cm}^{3} /\right.$ minute $)$

193

150

125

90

75

68.8

67.5

64.3

57.7

50.0
Cell Voltage (Volts)

1.60

1.60

1.60

1.60

1.60

1.61

1.64

1.64

1.72

1.74

*Total feed gas flow rate $\left(\mathrm{H}_{2}+\mathrm{N}_{2}\right)$ was $193 \mathrm{~cm}^{3} /$ minute while varying $\mathrm{H}_{2} / \mathrm{N}_{2}$ ratio. $\mathrm{H}_{2}$ consumption as consumed by the catalytic Pt anode was essentially constant at $67.5 \mathrm{~cm}^{3} /$ minute until the $\mathrm{H}_{2}$ feed rate went below that value, after which all the $\mathrm{H}_{2}$ was consumed. 


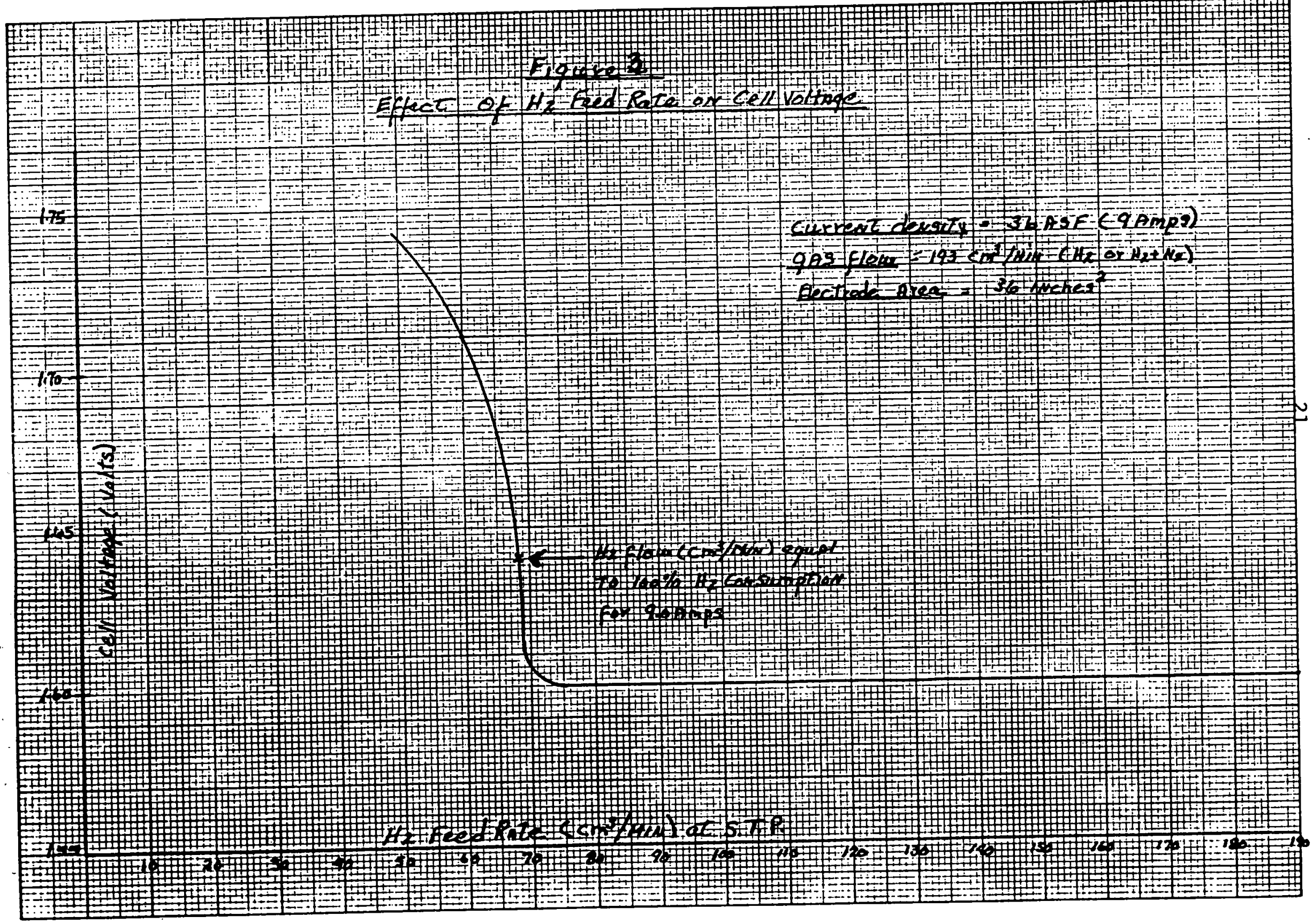


Pt anode performance, as measured by the full cell voltage. The presisure was adjusted by varying the depth of submersion in water of a tube connected to the $\mathrm{H}_{2}$ exit stream. The overall voltage drop was measured in a $6 " \mathrm{x} 6$ " cell operating at $36 \mathrm{ASF}, 55^{\circ} \mathrm{C}$, and a hydrogen feed rate $50 \%$ in excess of the minimum. Results are presented in Table 6 and Figure 4.

\subsubsection{Discussion}

Increasing the hydrogen back pressure from zero to $32 \mathrm{~cm} \mathrm{H}{ }_{2} \mathrm{O}$ (gauge; $1 \mathrm{~atm} \simeq 1033 \mathrm{~cm} \mathrm{H}_{2} \mathrm{O}$ ) results in a maximum 0.15 volt improvement in cell performance. This corresponds . 0 a power consumption decrease from 0.674 to 0.614 KWH/lb zinc, i.e., a saving of $0.06 \mathrm{kWH} / \mathrm{lb}$ zinc. The cell voltage initially drops sharply with increasing $\mathrm{H}_{2}$ back pressure and then decreases more slowly beyond a pressure of $10 \mathrm{~cm} \mathrm{II} 2 \mathrm{O}$.

Enhancing the hydrogen back pressure thus promotes the efficient functioning of the Pt electrode. This is due, at least in part, to the prevention of the liquid electrolyte's flooding the cloth electrode surface, and to the promotion of gaseous hydrogen diffusion into the catalytic surface.

It is conceivable that above a certain level of back pressure, one not reached in the experiments, there will either be damage to the electrode surface, or the liquid electrolyte will be prevented from penetrating the electrode surface. In the latter case, contact between hydrogen gas, 
TABLE 6

Effect of Hydrogen Gas Backpressure upon

the Catalytic Pt Anode Performance

Experimental Conditions:

Current Density: 36 ASF

Cell Size: 6" $\times 6^{n}$

Electrolyte: $\quad 130 \mathrm{~g} / 1 \mathrm{zn}^{++}$

$100 \mathrm{~g} / 1 \mathrm{H}_{2} \mathrm{SO}_{4}$

$0.1 \mathrm{~g} / 1$ Animal Glue

Temperature: $55^{\circ} \mathrm{C}$

$\mathrm{H}_{2}$ Excess: $\quad 508$

$\mathrm{H}_{2}$ Gas Backpressure $\left(\mathrm{cm} \mathrm{H}_{2} \mathrm{O}\right)$

Cell Voltage (Volts)

0

1.68

1.0

1.66

2.0

1.65

5.0

1.63

9.5

1.60

12.0

1.59

14.0

1.58

16.5

1.57

20.0

1.56

24.0

1.55

28.0

1.54

32.0

1.53 


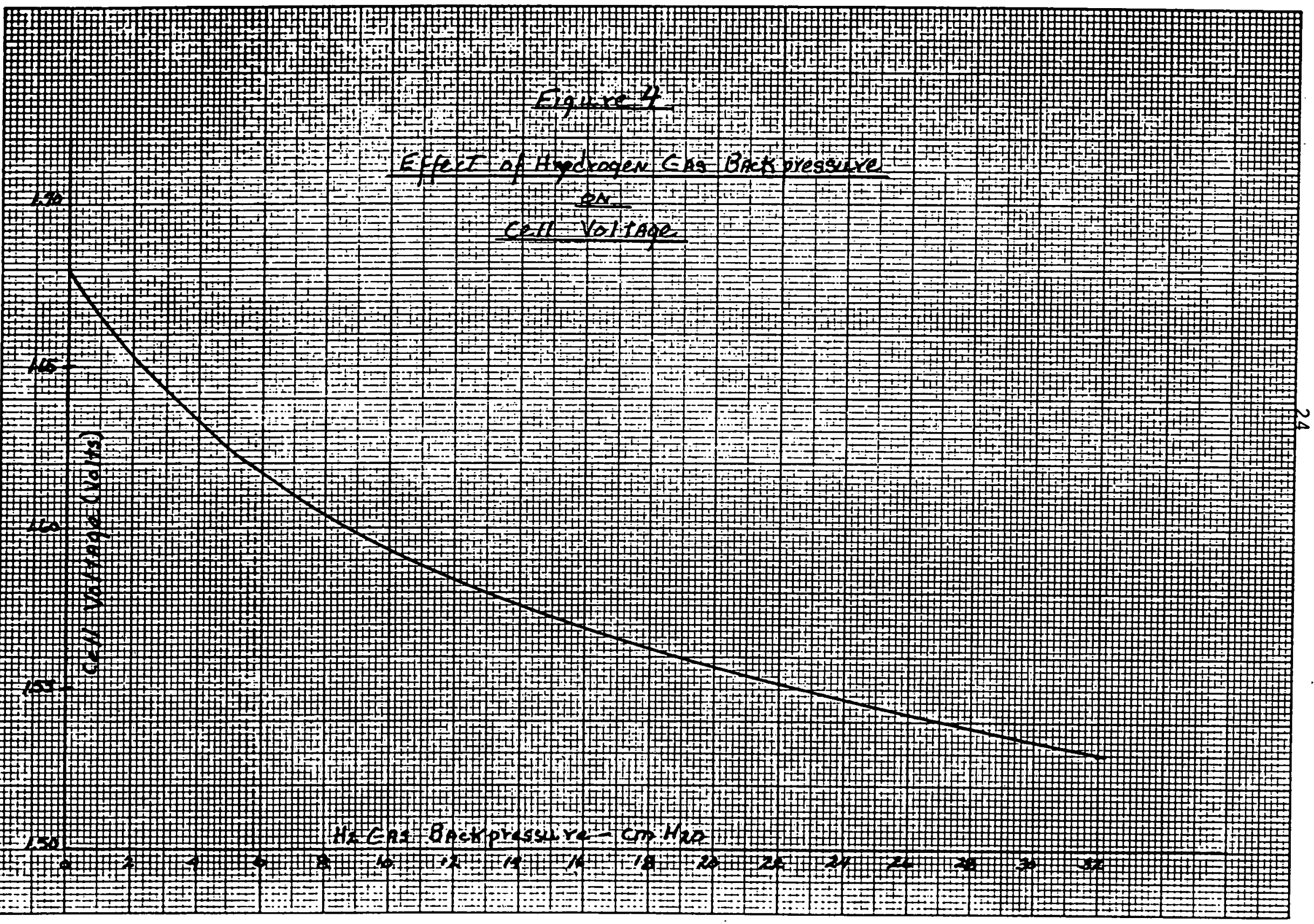


$\mathrm{H}^{+}$-containing liquid electrolyte and solid catalytic electrode will be sub-optimal, and the cell voltage will again rise; i.e., there will be a minimum in the curve of cell voltage vs. $\mathrm{H}_{2}$ back pressure. The optimal back pressure would have to be determined in a pilot plant size cell, with electrode construction material and cell assembly analogous to those of the ultimate industrial unit.

3.7 The Effect of Current Density upon Energy Consumption and Current Efficiency at Various $\mathrm{Zn}^{++}$Concentrations

\subsubsection{Introduction}

In section 3.4 the $\mathrm{Zn}^{++}$concentration was shown to affect both current efficiency and energy consumption, at a constant current density and acid concentration. In this section we report the effects of varying current density and $\mathrm{Zn}^{++}$concentration upon energy consumption and current efficiency. Results obtained at $55^{\circ}$. with a $6 "$ × $6 "$ cell are presented in Table 7 and Figure 5. These results complement those presented in section 3.2 .

\subsubsection{Discussion}

It is generally accepted in the zinc electrowinning literature ${ }^{l}$ that, all else being equal, current efficiency increases somewhat with the applied current density and that the energy consumption (in $\mathrm{KWH} / \mathrm{lb}$ inc) is directly related to the current density.

I. I.W. Wark, "The Electrodeposition of zinc from Acidified Zinc Solution," J. Appl. Electrochem. 9, 721 (1979). 
TABLE 7

The Effect of Current Density upon Energy

Consumption and Current Efficiency at Various $\mathrm{Zn}^{++}$Concentrations

Experimental Conditions:

Cell: 6" 6 6"

Anode Loading: $0.30 \mathrm{mg} \mathrm{Pt} / \mathrm{cm}^{2}$

Temp: $\quad 55^{\circ} \mathrm{C}$

$\mathrm{H}_{2} \mathrm{SO}_{4}: 100 \mathrm{~g} / 1$

Animal Glue: $0.1 \mathrm{~g} / \mathrm{l}$

Steady state feed and bleed

$$
\mathrm{pH}-5 \text { filtered (B \&W) } \mathrm{ZnSO}_{4}
$$

\begin{tabular}{|c|c|c|c|c|c|}
\hline $\begin{array}{l}\text { Experiment } \\
\text { Number }\end{array}$ & $\begin{array}{l}\mathrm{Zn}^{++} \\
(g / 1)\end{array}$ & $\begin{array}{c}\text { Current } \\
\text { Density } \\
\text { (ASF) }\end{array}$ & $\begin{array}{l}\text { Duration of } \\
\text { Run* (Hours) }\end{array}$ & $\begin{array}{c}\text { Current } \\
\text { Efficiency }\end{array}$ & $\begin{array}{l}\text { Energy } \\
\text { Consumption } \\
\text { (kWH/lb Zinc) }\end{array}$ \\
\hline $\begin{array}{l}1 \\
2 \\
3 \\
4 \\
5\end{array}$ & $\begin{array}{l}50 \\
50 \\
50 \\
50 \\
50\end{array}$ & $\begin{array}{l}36 \\
45 \\
54 \\
72 \\
90\end{array}$ & $\begin{array}{l}8.0 \\
6.4 \\
5.3 \\
4.0 \\
3.2\end{array}$ & $\begin{array}{l}87.7 \% \\
87.4 \% \\
86.9 \% \\
87.5 \% \\
87.3 \%\end{array}$ & $\begin{array}{l}0.59 \\
0.65 \\
0.68 \\
0.78 \\
0.80\end{array}$ \\
\hline 6 & 50 & 90 & $8.0 * \star$ & $85.1 \%$ & 0.91 \\
\hline $\begin{array}{l}7 \\
8 \\
9 \\
-\end{array}$ & $\begin{array}{l}80 \\
80 \\
80\end{array}$ & $\begin{array}{l}36 \\
54 \\
90\end{array}$ & $\begin{array}{l}8.0 \\
5.3 \\
3.2 \\
\end{array}$ & $\begin{array}{l}89.2 \% \\
91.4 \% \\
94.3 \%\end{array}$ & $\begin{array}{l}0.61 \\
0.71 \\
0.98\end{array}$ \\
\hline 10 & 80 & 90 & $8.0 * *$ & $93.0 \%$ & 0.99 \\
\hline $\begin{array}{l}11 \\
12 \\
13 \\
--\end{array}$ & $\begin{array}{l}90 \\
90 \\
90 \\
-\end{array}$ & $\begin{array}{l}36 \\
54 \\
90\end{array}$ & $\begin{array}{l}8.0 \\
5.3 \\
3.2\end{array}$ & $\begin{array}{l}91.0 \% \\
93.6 \% \\
94.7 \%\end{array}$ & $\begin{array}{l}0.63 \\
0.76 \\
1.00\end{array}$ \\
\hline 14 & 90 & 90 & $8.0 * *$ & 93.38 & 1.00 . \\
\hline
\end{tabular}

* Run duration was selected to equalize the deposits at each current density.

* * At each zinc concentration a longer ( 8 hours) run was conducted to yield an approximately commercial size thickness of zinc plate. 


\section{\& Current}

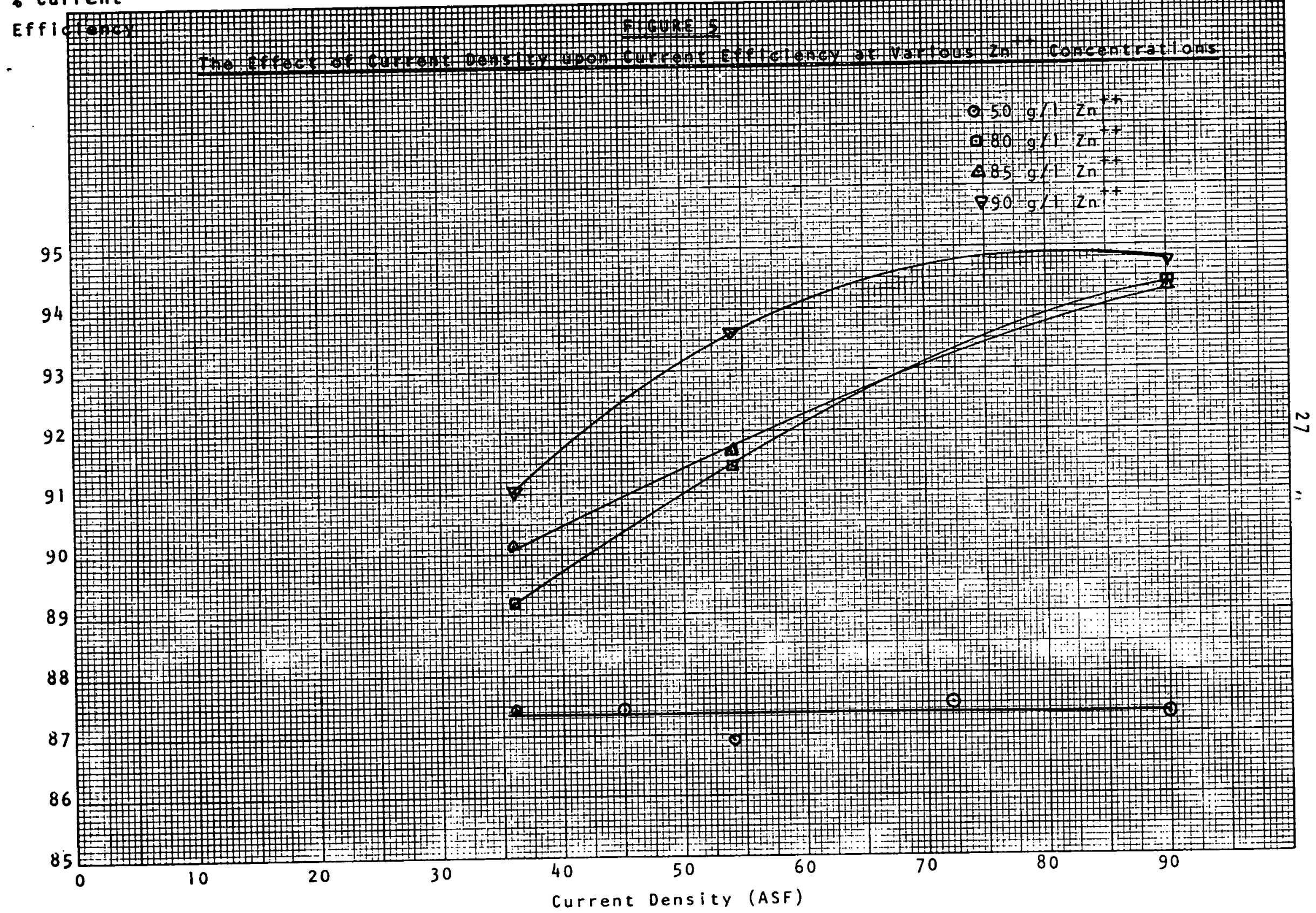


The current efficiency-current density relationship holds only partially. At a relatively high acid to $\mathrm{Zn}^{++}$ concentration ratio $(100: 50$ in $\mathrm{gm} / 1)$, the current efficiency values are all below $90 \%$ and appear to be effectively independent of current density over a wide range of current densities (36-90 ASF). Additional results (Table 2) show that at current densities as high as $144 \mathrm{ASF}$, and under the same experimental conditions, the current efficiency does not exceed $88 \%$. However, as the ratio of the dissolved acid to $\mathrm{Zn}^{++}$concentration decreases from a value of 100:50, the current efficiency becomes dependent upon current density as expected.

At the constant acid concentration of $100 \mathrm{~g} / 1 \mathrm{H}_{2} \mathrm{SO}_{4}$, the energy consumed per $1 \mathrm{~b}$ of $\mathrm{zinc}$ deposited increases with both the current density and the $\mathrm{Zn}^{++}$concentration. Its increase with the current density (which is offset by increasing rates of zinc deposition) is related to energy losses associated mostly with heat generation. The increase in energy consumption with $\mathrm{Zn}^{++}$concentration, at fixed current density and acid concentration, is related to the corresponding decrease in electrolyte conductivity (see Figure 2).

3.8 Trace Analysis of a Commercial-Size Thickness Cathodic Zinc Plate Produced Using the Catalytic $\mathrm{H}_{2}$ Electrode

\subsubsection{Introduction}

The cathodic zinc plate produced under the conditions of experiment 14 in Table 7 was submitted for a trace element 
analysis. The results are summarized in Table 8 , where they are compared with the trace analysis of the feed solution from which the zinc plate was deposited.

\subsubsection{Discussion}

Impurity metals having a redox potential more negative than zinc (in the reaction: $\mathrm{Zn} \rightarrow \mathrm{Zn}^{++}+2 \mathrm{e}^{-}$) tend to deposit along with the zinc at the cathode plate. These metals include $\mathrm{Cd}, \mathrm{Cu}, \mathrm{Ag}$ and $\mathrm{Pb}$.

In light of literature data $\mathrm{I}$ and in the opinion of Anaconda's zinc experts, the analysis of the feed solution indicates a typical and acceptable impurity content of plant feed. The amount of impurities found in the cathodic zinc plate is also typical of industrial zinc electrodeposition plates and, in Anaconda's judgment, indicates very good quality cathodic zinc.

Table 8 shows that $C d$ in particular tends to be depleted preferentially at the zinc cathode. The analysis also shows that $\mathrm{Mn}^{++}$ion, present in fairly large amounts in the feed solution, does not contaminate the cathode-deposted zinc plate. The sulfur content of the cathodic plate is usually taken as an indicator of the plate's porosity. The more porous the plate, the more $\mathrm{H}_{2} \mathrm{SO}_{4}$ solution is trapped in the pores, and thus the higher the sulfur content. In Anaconda's judgment, the observed sulfur content (<10 ppm) signifies a desireably solid, nonporous cathodic plate.

1. AIME World Symposium on Mining and Metallurgy of Lead and Zinc, Vol. II, The Am. Inst. of Mining, Metallurgy and Petroleur, Eng. Inc., NYC, 1970. 


\section{$\therefore \quad$ TABLE 8 \\ Trace Analysis of a Cathodic $\mathrm{Zn}$ plate Produced by the $\mathrm{H}_{2}$ Catalytic Pt Anode}

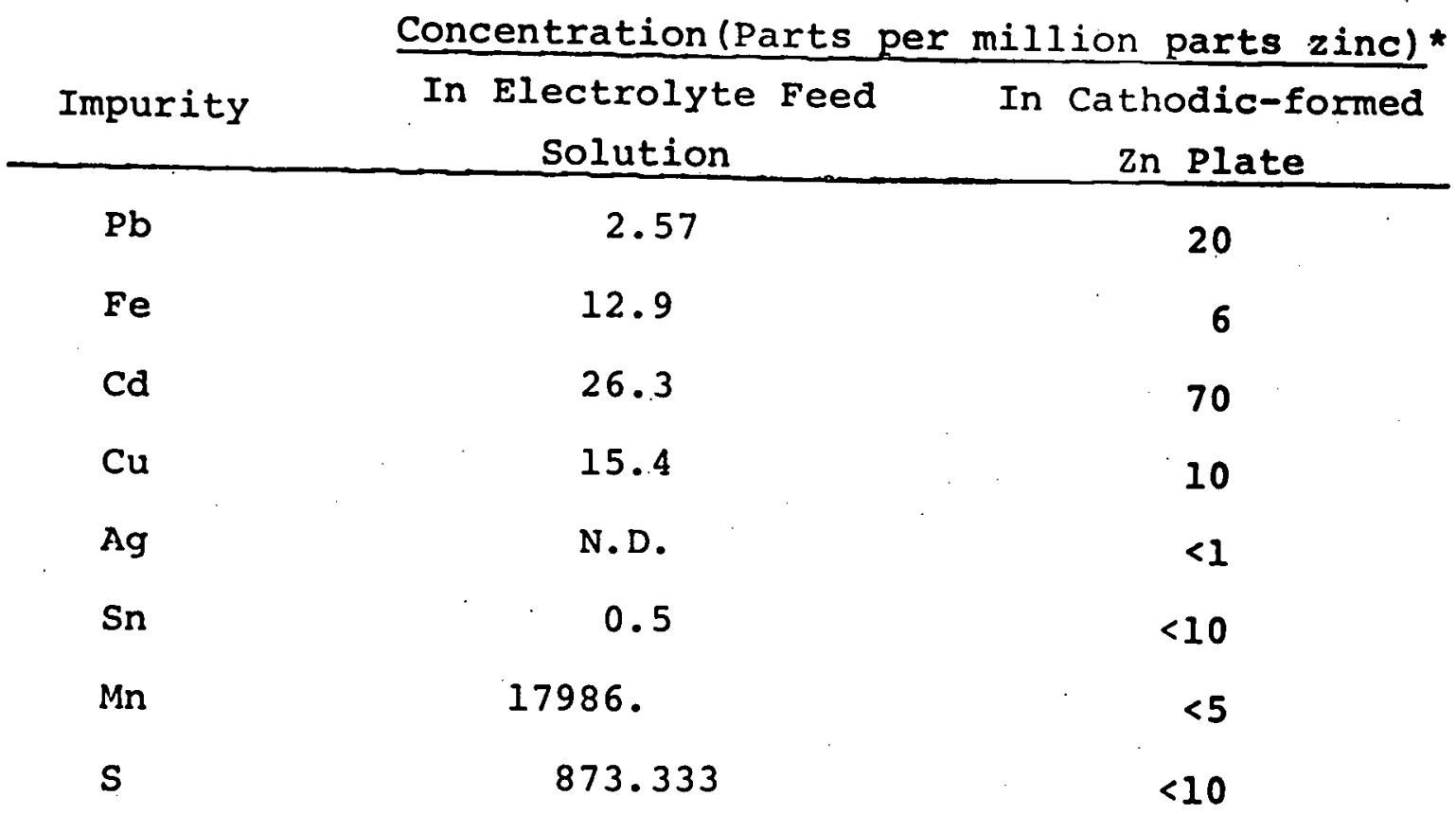

* The analyses were performed by the analytical laboratories of the Anaconda Company. 
3.9 Further Comparison of the Effects of Feed Solution Purification Procedures

\subsubsection{Introduction}

In section 3.4 we reported the results of experiments conducted in the $2 " x 2$ " cell, in which the performance using plant feed solution (1) has been compared with that using purified non-filtered $\mathrm{ZnSO}_{4}(B \& W$ ) solution (2) and pH-5 filtered solution(3). Additional purification procedures have been investigated: (4) Air stream dissolution and oxidation of the feed solution at $\mathrm{pH}-5$, followed by filtration of all solids at the same $\mathrm{pH} ;$ (5) Air stream dissolution and oxidation at $\mathrm{pH}-5$, followed by filtration, zinc dust treatment (zinc dust added to the extent of $10 \%$ of the total zinc content in the feed solution) and refiltration. Table 9 summarizes the results obtained with the 6" $x$ " cell variously purified solutions, under varying experimental conditions.

\subsubsection{Discussion}

From the results presented in Table 9 it may be concluded that there is essentially no effect of method of feed purification (1)-(5) upon cell performance, as measured by current efficiency and power consumption. This agrees with data for the $2 " \times 2 "$ cell as reported in section 3.4 .

At a given $\mathrm{Zn}^{++}$concentration there is a very slight increase in current efficiency, with practically no change in the energy consumption, in going from purification methods 


\section{TABLE 9}

The Effect of Various Purification Procedures and zinc Concentrations upon Cell Performance

Experimental Conditions:
$\mathrm{H}_{2} \mathrm{SO}_{4}: 100 \mathrm{~g} / 1$
Animal Glue: $0.1 \mathrm{~g} / \mathrm{l}$
Temp: $\quad 55^{\circ} \mathrm{C}$

Steady state feed and bleed

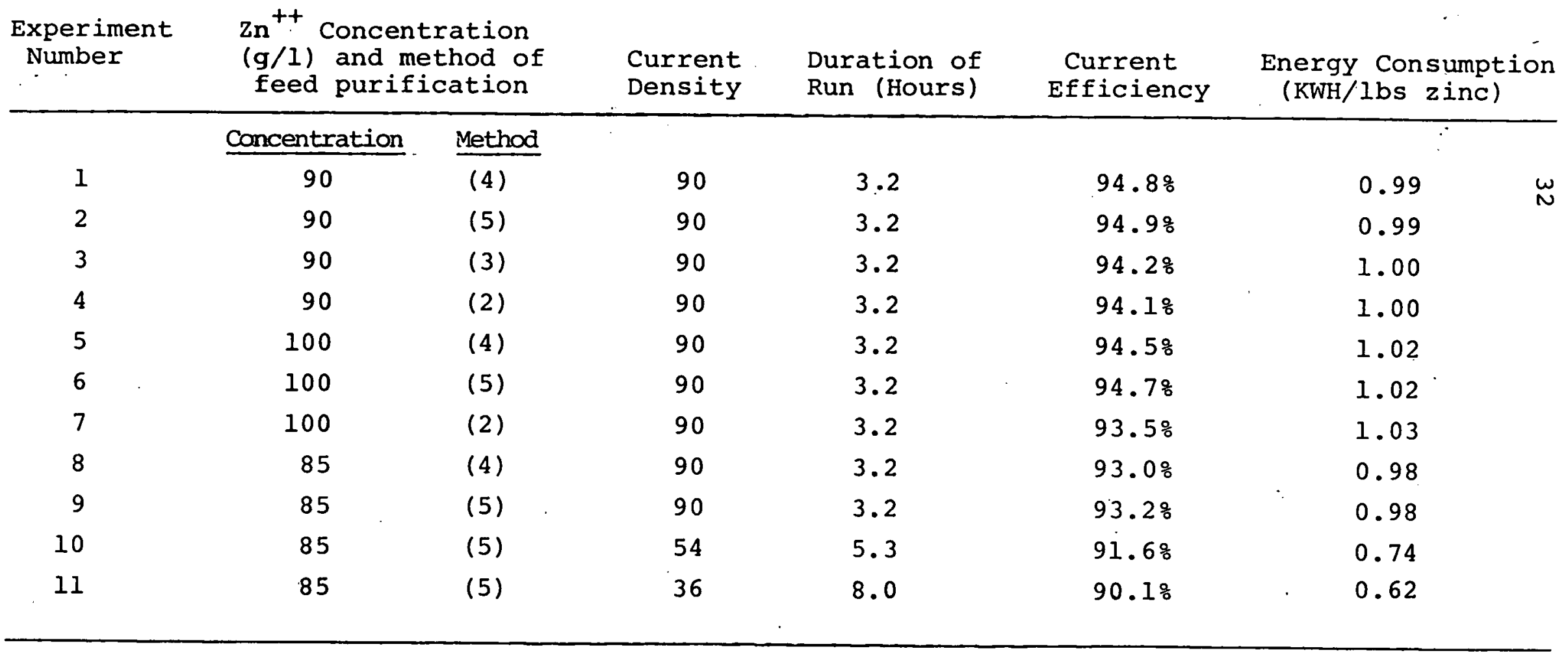


(2) and (3) to (4) and (5) (compare experiments 1 and 2 with 3 and 4 , and compare 5 and 6 with 7 ).

In addition, experiments 9,10 and 11 confirm the effects of current density upon current efficiency and power consumption, as discussed in section 3.5. Similarly, comparison of experiments 2,6 and 9 reveals again the effects of $\mathrm{Zn}^{++}$concentration upon current efficiency and power consumption, as also discussed in section 3.7 .

It can generally be concluded that i) the various purifications methods so far attempted have essentially no influence upon cell performance, and ii) the performance at a given set of conditions (i.e., acid concentration, temperature, current density, and duration of run) is determined mostly by the acid to $\mathrm{Zn}^{++}$concentration ratio.

It is conceivable, however, that extended purification following the industrial methods step by step could further improve the current efficiencies with solutions of high acid to zinc ratio.

3.10 Comparison of Performance of Four Different 6" $\times$ 6" Platinum Anodes Produced by the Prototech Company

\subsection{0 .1 Introduction}

Four different 6" $\times 6 "$ anodes produced by the Prototech Company were tested in the 6" $\times$ 6" zinc deposition cell under identical experimental conditions. The pt loading of each anode is listed in Table 10, while a comparision of anode performance is made in Table 11. See also the discharge curves (cell voltage vs. current density) of Figure 6 . 
TABLE 10

Comparison of Platinum Loadings of Four Prototech Company Catalytic Anodes

Anode Number

1

2

3

4
Pt Loading (mg $\left.\mathrm{Pt} / \mathrm{cm}^{2}\right)$

0.33

0.30

0.30

0.29 


\section{TABLE 11}

Comparison of Performance of Four

Prototech Company Catalytic Pt Anodes

Experimental Conditions:
$1.00 \mathrm{~g} / 1 \mathrm{zn}^{++}$
$\mathrm{H}_{2} \mathrm{SO}_{4}: 100 \mathrm{~g} / 1$
Temp: $\quad 55^{\circ} \mathrm{C}$

Animal Glue: $0.1 \mathrm{~g} / 1$

steady State feed and bleed

Current Density

(ASF)

0

9

10

27

36

45

54

63

72

81

90
Cell Voltage (volts)

$\frac{\text { Anode Number }}{2}$

4

1

0.74

0.75

0.75

0.76

0.98

1.03

1.00

0.99

1.16

1.20

1.18

1.17

1.36

1.37

1.36

1.35

1.52

1.56

1.53

1.53

1.68

1.71

1.70

1.71

1.85

1.89

1.88

1.89

2.01

2.06

2.05

2.08

2.19

2.26

2.23

2.26

2.36

2.42

2.40

2.44

2.55

2.59

2.58

2.63 


\subsubsection{Discussion}

The data of Table 10 indicate little difference among the four 6" $\times$ 6" Pt anodes, and suggest that they should be nearly equally effective. It should also be noted that anode \# 1 had been used in the $\mathrm{zn}^{++}$cell. for several hundred hours, anode \#2 for ca. 200 hours, and anodes \#3 and \#4 for a few tenths of an hour. No significant difference in performance is indicated with any of the above four anodes.

Figure 6 shows a typical discharge curve for anode \#3 (the curves for the four anodes practically overlap, and therefore only one has been drawn). Since the discharge curve remains linear up to 9.0 ASF (22.5 Amps applied current) there is no apparent significant change in anode polarizatin or IR drop at that current density. Furthermore, we have ample reason to believe that even higher current densities are feasible using the Prototech Pt hydrogen anode. 


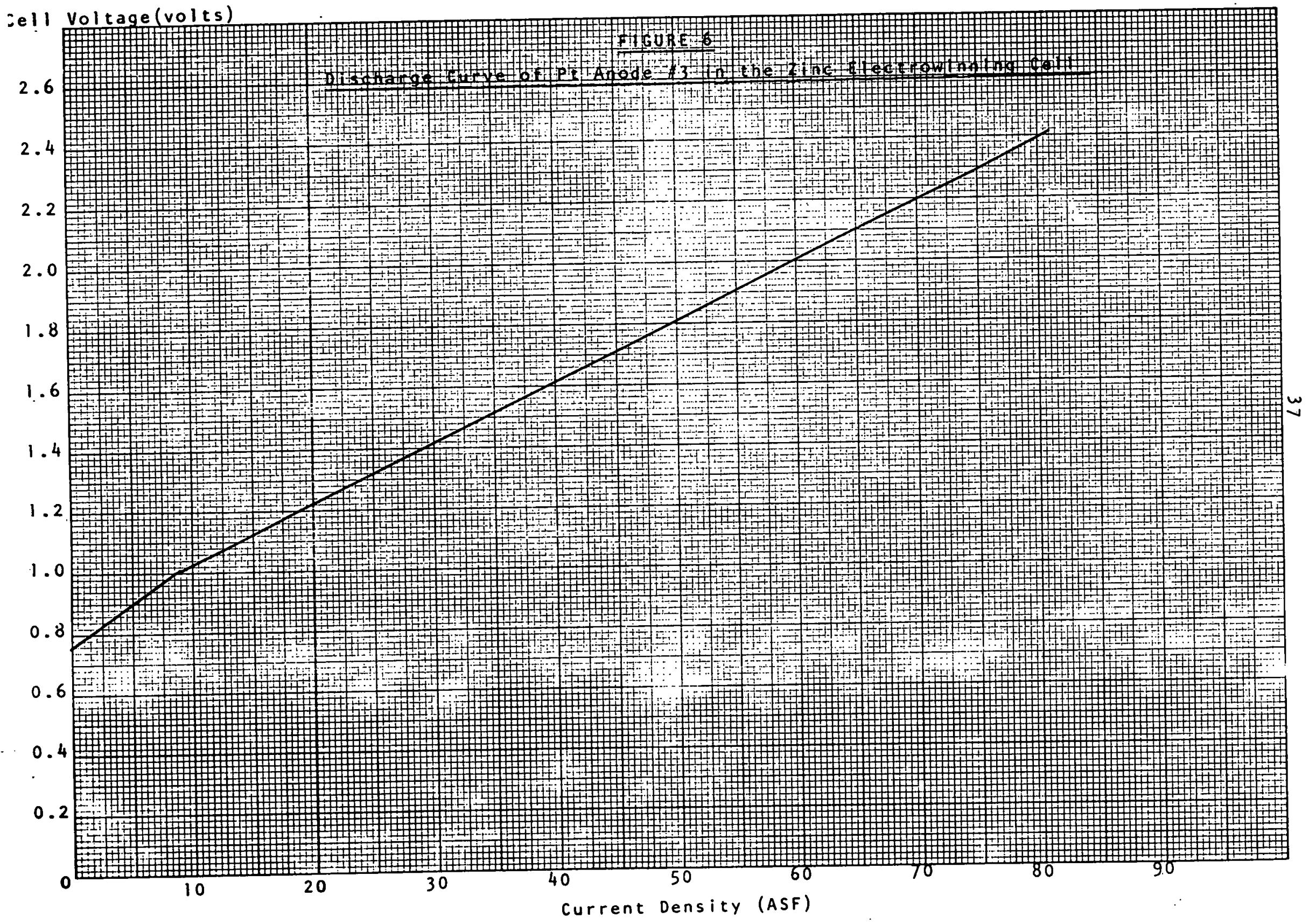

